PRODUCTION

ENGINEERING

ARCHIVES
2016, Vol. 10, No 1, pp 29-32

ISSN 2353-5156

ISSN 2353-7779 (print version)

(online version)

Article history:

\title{
Increasing competitiveness with intercompany integration of logistics and marketing functions
}

\author{
Darja Topolšek $^{1}$, Borut Jereb ${ }^{2}$, Tina Cvahte ${ }^{3}$ \\ ${ }^{1}$ Assistant professor, University of Maribor, Faculty of Logistics, Mariborska 7, SI-3000 Celje, Slovenia, darja.topolsek@um.si \\ ${ }^{2}$ Associate professor, University of Maribor, Faculty of Logistics, Mariborska 7, SI-3000 Celje, Slovenia, borut.jereb@um.si \\ ${ }^{3}$ Teaching assistant, University of Maribor, Faculty of Logistics, Mariborska 7, SI-3000 Celje, Slovenia, tina.cvahte@um.si
}

\begin{abstract}
Researchers of different scientific disciplines, such as management strategies, organizational theories and marketing, have in the past explored relations of mutual influences and the importance of cooperation between different functions in a company. The increased focus on the logistics function has potential to increase competitiveness. This is especially true for globally aimed production companies. In any company, logistics functions cooperate with various related functions such as production, marketing, procurement, engineering or developing new products as well as with financial functions. Each of the aforementioned connections or cooperation among logistics and its complementary functions can have a decisive effect on the company's competitiveness. Using a survey, we determined which activities in the surveyed companies are performed by the logistical function together with the marketing function and which activities they suggest should be performed together but are currently not, meaning they are co-dependent. Since interfunctional integration between logistics and marketing increases the success of a company, we also examined the connection between the current joint performance of activities and the suggested joint performance of activities among the before mentioned sectors, connected to the effectiveness of the company. To examine the mentioned connections among the logistical and marketing functions, Explanatory Factor Analysis (EFA), Confirmatory Factor Analysis (CFA) and Structural Equation Modelling (SEM) were performed.
\end{abstract}

Key words - Integration, Logistics, Marketing, SEM

\section{Introduction}

Logistical functions cooperate (are connected) with different interconnected functions such as production, marketing, procurement (GUSTIN C. M. 1991), engineering or new product development (GUSTIN C. M., 1991) and with financial functions as well (COYLE J. J., BARDI E. J.\& LANGLEY J. C. 2003).

Traditionally, many companies are organized around marketing and production functions. This is not unusual, since marketing means selling something, while manufacturing or production represents the production of something; nonetheless, it is necessary to look at a company on a higher level (BALLOUR. H.2004).

Logistics must be closely connected to production and marketing, as only as such it can plan, coordinate and integrate their cross-functional activities (MORASH E. A., DRÖGE C.\&VICKERY S. 1997).

Marketing is thus basically responsible for market research, promotion, sales management and product availability. Production/operations refer to the creation of a product or a service which creates value of the 
product because of its shape. Logistics is hidden in these activities and gives the product or service the value of time and place. This separation of activities into three groups, and not into two, is not always necessary or even advisable. Logistical activities may in fact be coordinated otherwise. Marketing and production systems/operations may successfully carry out logistics activities without creating additional organizational entities.

Various authors differently interpret the integration and cooperation between functions in a company. The integration of logistics and marketing function is a process of interaction and collaboration, in which logistics and marketing functions work together in a cooperative mode to achieve mutually acceptable results for the company.

Logistics and marketing functions are now already integrated to a certain level in many companies, but BOWERSOX D. J., Closs D. J. andStanK T. P.(2008) show two catalysts or initiators for the classification of logistics into a system of key strategic resources. These two catalysts are time and competition, based on quality, efficiency and effectiveness. These factors seek to eliminate wastage of time, effort, incomplete units and supplies in the production-distribution system (SCHULTZ D. P.1985). The most common concepts, which are based on time and quality, are Just in time - JIT and Quick response - QR. Typically, positive effects from such concepts are fully utilized only if the logistic function is internally integrated with marketing.

Recently, researchers have highlighted the need to increase the level of cross-functional collaboration between logistics and marketing, whereas the latter increases the performance of the company (KAHN K. B. \&MentZerJ. T. 1998; MoRASh E. A., DRÖGE C.\& VICKERY S.1997). BOWERSOX D. J., ClOSS D. J., and STANK T. P.(2000) made an initiative claiming that the improvement of integration between logistics and marketing function is crucial to the success of companies in the 21 st century. The success of the company is to be understood as the sum of performance of teams, departments and individuals. That is why companies recently place great emphasis on assessing work performance, staff motivation, development of human and intellectual capital.
Based on the given facts, it can be concluded that the integration of logistics and marketing functions is crucial to the success of the company. On this basis, this study focuses on which activities of logistics and marketing functions are actually carried out jointly, and which activities should be carried out together and interdependently. Because of that, the main research field of this research is focused on the implementation of joint actions and the impact there of on the performance of the company.

\section{Methodology of research}

To determine the relation between the current state of implementation of the activities, the proposed state of implementation of the activities, and performance of the company, an anonymous survey was carried out among Slovenian companies. The sample of enterprises was based on a predetermined scope, represented by companies whose business is defined as Retail trade, except for motor vehicles.

In the analysis, we dealt with 78 correctly completed questionnaires. The questionnaire is comprised of two main sets of questions that relate to the implementation of the activities and performance of the company. All questions were answered by employees in the logistics sector as well as in the sector of marketing.

Respondents evaluated the existing state of implementation of activities and the proposed status of implementation of activities on a Likert scale (1 Never, 5 Always). We also evaluated the performance of the company from the perspective of four items on a Likert scale (1 Very Low, 5 Very High).

Table 1: Variable names

\begin{tabular}{|l|l|l|}
\hline \multicolumn{2}{|c|}{$\begin{array}{l}\text { Which activities are performed together (left side) and which activities } \\
\text { should be performed together (right side) }\end{array}$} \\
\hline $\begin{array}{l}\text { Variable } \\
\text { current } \\
\text { state }\end{array}$ & Description & $\begin{array}{l}\text { Variable- } \\
\text { suggestedstate }\end{array}$ \\
\hline CURR_1 & Transport & SUGG_1 \\
\hline CURR_2 & Warehousing and storage of goods & SUGG_2 \\
\hline CURR_3 & Industrial packaging & SUGG_3 \\
\hline CURR_4 & Goods manipulations & SUGG_4 \\
\hline CURR_5 & Maintenance of stock & SUGG_5 \\
\hline CURR_6 & Order processing & SUGG_6 \\
\hline CURR_7 & Demand predictions & SUGG_7 \\
\hline CURR_8 & Production planning & SUGG_8 \\
\hline CURR_9 & Procurement & SUGG_9 \\
\hline CURR_10 & Consumer support & SUGG_10 \\
\hline
\end{tabular}




\begin{tabular}{|l|l|l|}
\hline CURR_11 & $\begin{array}{l}\text { Location of production and storage facili- } \\
\text { ties }\end{array}$ & SUGG_11 \\
\hline CURR_12 & Handling of returned goods & SUGG_12 \\
\hline CURR_13 & $\begin{array}{l}\text { Support to service activities and supply of } \\
\text { spare parts }\end{array}$ & SUGG_13 \\
\hline CURR_14 & $\begin{array}{l}\text { Solving problems with waste and their } \\
\text { disposal or recycling }\end{array}$ & SUGG_14 \\
\hline CURR_15 & $\begin{array}{l}\text { Designing specific characteristics of the } \\
\text { product or service from the view of useful- } \\
\text { ness, quality or design }\end{array}$ & SUGG_15 \\
\hline CURR_16 & Packaging design \\
\hline \multicolumn{3}{|l|}{ Assessment of performance of the company } \\
\hline Variable & \multicolumn{2}{|l|}{} \\
\hline PERF_1 & $\begin{array}{l}\text { My company has achieved a reduction in the costs services } \\
\text { that we have in order to meet the specific requirements of a } \\
\text { certain consumer }\end{array}$ \\
\hline PERF_2 & $\begin{array}{l}\text { My company has achieved a reduction in costs in transporting } \\
\text { certain goods to certain consumers }\end{array}$ \\
\hline PERF_3 & $\begin{array}{l}\text { My company has achieved a reduction in costs in the pro- } \\
\text { cessing of certain orders of certain consumers }\end{array}$ \\
\hline PERF_4 & $\begin{array}{l}\text { My company has achieved a reduction in outgoing stocks of a } \\
\text { given product for a given consumer }\end{array}$ \\
\hline PERF_5 & $\begin{array}{l}\text { My company has achieved a reduction in the delivery time for } \\
\text { a given consumer }\end{array}$ \\
\hline
\end{tabular}

To explore the problem defined, a statistical analysis was carried out, which included exploratory factor analysis (EFA) and confirmatory factor analysis (CFA) as well as structural equation modelling (SEM).

\section{Results}

With the help of a questionnaire we measured what activities respondents from both sectors (logistics and marketing) actually carried out jointly and which activities the respondents proposed to be carried out jointly or interdependently between sectors.

Basic developed insights suggest that the perception of the implementation of interdependent activities among employees in complementary functions varies considerably. We note the continuing differences in the responses of employees in the marketing function in comparison to the answers of employees in the logistics function, from which we detect some noncompliance and poor understanding of the actual implementation of activities.

\section{EFA and CFA}

Exploratory factor analysis (EFA) is designed for situations where the links between the observed and latent variables are unknown or uncertain. Based on a normality test we can conclude that the distribution is normal, which allows for the use of Maximum Likeli- hood estimation. To determine reliability, the Bartlett's test of sphericity (BTS) and the Kaiser-MeyerOlkin(KMO) test were also conducted. The BTS value was highly significant $(=2798.229$ with $\mathrm{df}=276$ and $\mathrm{p}<0.001$ ), while the value of KMO was $0.736>0.05$. Therefore we can claim that factor analysis is reliable. Item loadings on factors were significant, since they reached the value 0.40 or more.

The EFA resulted in 3 factors - see Figure 1 for details. It is evident that the variables concerning the current state (CURR), suggested activities (SUGG) and company's performance (PERF) are significantly loaded on the corresponding factors. Loading factors resulting from EFA were assigned to confirmatory factor analysis (CFA). Based on the assumption of multivariate normality, the maximum likelihood (ML) method was used.

\section{Structural equation model}

Six steps of SEM modelling were performed as recommended by Kline (2005). In SEM the maximum likelihood (ML) estimation method was used.

Figure 1 shows SEM results, where the estimated path coefficients are significant at $\mathrm{p} \leq 0.10$ level among the variables.

The latent variable CURR for currently jointly performed activities was constructed with 7 measured variables. From the path coefficient, it is obvious that the maximum value is that of the CURR 14 (Solving problems with waste and their disposal or recycling) and of CURR15 (Designing specific characteristics of the product or service from the view of usefulness, quality or design). This means that these two variables are most commonly presented and are most commonly performed together with a complementary business function.

The latent variable SUGG is comprised of 14 measured variables, among which SUGG_4 (Goods manipulation) in SUGG_5 (Maintenance of stock) stand out, meaning that they are the most important activities for cooperation.

For PERF variables, the EFA and CFA revealed 4 latent variables, among which PERF_2 (Reduction in transport costs) has the largest coefficient and is therefore the most important factor in a company's performance and success. 
The SEM results also identified 3 significant relations among the latent variables. First negative relation is between current performance of activities and effectiveness. This shows that current joint performance of activities is not at a satisfactory level and even has a negative effect on the company's performance. On the other side, results show an important positive relation between the suggested performance of activities together with other functions and the company's performance. This leads to the conclusion that such companies are on the path towards economical success.

\section{Figure 1: Results of the SEM model and coefficients} of relations

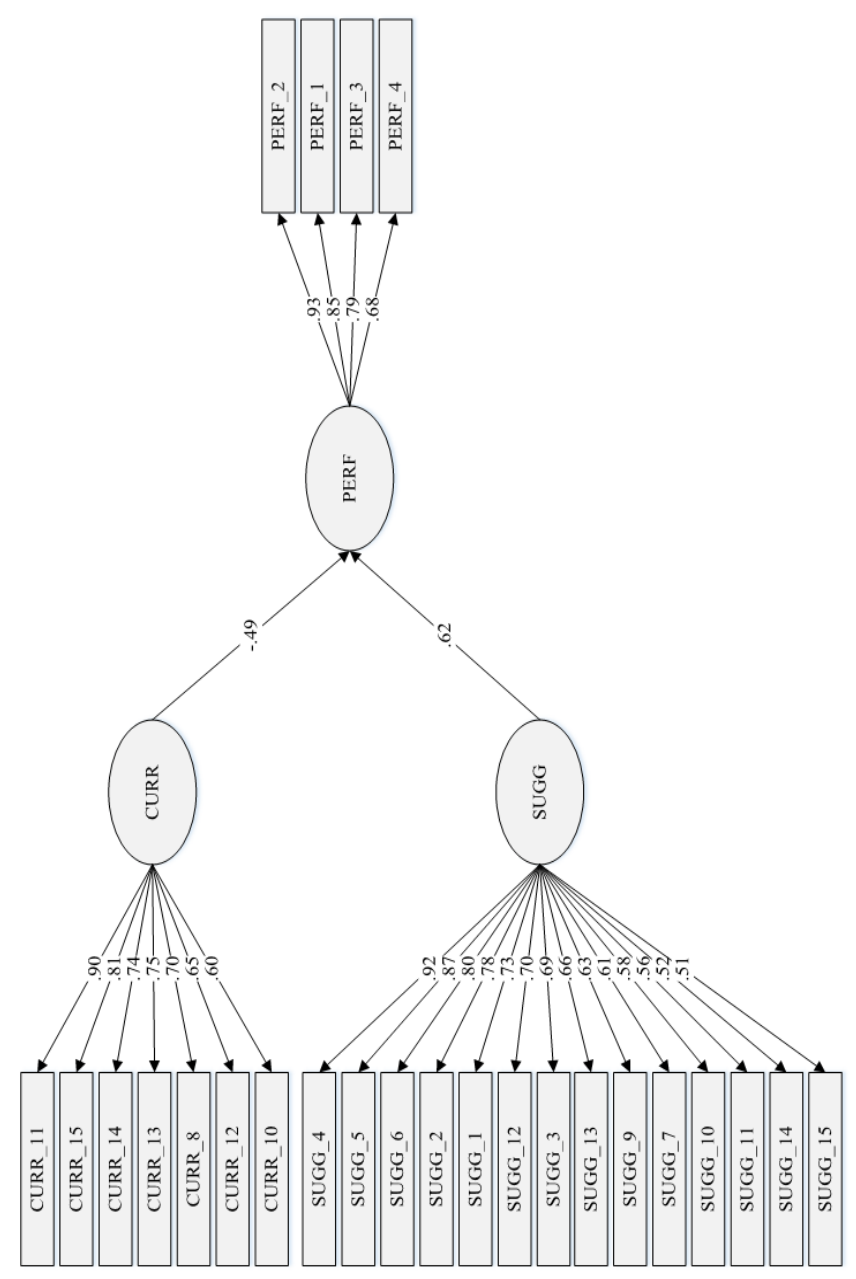

All indices of model fit are inside the allowed limits or surpass the given minimal values (Chi-Square $=$ 2411.883; Relative Chi-Square of the discrepancy $=$ 8.867; RMSEA $=0.032 ; \mathrm{NFI}=0.961 ; \mathrm{CFI}=0.978$; IFI $=0.985 ;$ SRMR $=0.0562)$.

\section{Conclusion}

The paper presented one of the most important aspects of a company's operations - its internal integration of different functions, most importantly the logistics and marketing functions. Previous studies show that internal integration of various functions, and also of the marketing and logistics functions, bring benefits to company operations. Our study confirms this premise and expands on it, showing that the interdependence of the logistics and marketing function is indeed important, and importantly contributes to the set measures of a company's performance.

We showed that the current state of interdependence and joint performance of activities is not on a desired level and therefore, the company performance suffers from it. However, in the case of joint performance on a suggested level, the company's performance would increase significantly and aid the overall company effectiveness and efficiency.

\section{Bibliography}

1. BALlou R. H. (2004). Business Logistics/Supply Chain Management, Planning, Organizing, and Controlling the Supply Chain. Pearson Prentice Hall. New Jersey.

2. Bowersox D. J., Closs D. J. \& Stank T. P. (2000). Ten Mega-Trends that Will Revolutionize Supply Chain Logistics. "Journal of Business Logistics", 21 (2), 1-17.

3. COYle J. J., Bardi E. J. \& LANGley J. C. JR. (2003). The Management of Business Logistics, A Supply Chain Perspective. South-Western Thomson Learning. Ohio, USA.

4. Gustin C. M. (1991). Integrated Logistics: The Perceptions and the Future. "Production and Inventory Management", 11 (6), 1-4.

5. KAHN K. B. \&MENTZER J. T. (1998). Marketing's Integration with Other Departments. "Journal of business research", 42 (1), 53-62.

6. Morash E. A., DrÖGE C. \& ViCKerY S. (1997). Boundary-spanning interfaces between logistics, production, marketing and new product development. "International Journal of Physical Management", 27 (5/6), 43-62.

7. SChultz D. P. (1985). Just-in-time system. Stores. New York, USA. 